\title{
Mutagenicity and antimutagenicity of Salacia crassifolia (mart. Ex. Schult.) G. Don. evaluated by Ames test
}

\author{
C. C. Carneiro ${ }^{a *}, J$. Holanda Véras ${ }^{a}$, B. R. Lima Góes ${ }^{a}$, C. N. Pérez ${ }^{b}$ and L. Chen-Chen ${ }^{a}$ \\ a'Departamento de Genética, Instituto de Ciências Biológicas, Universidade Federal de Goiás - UFG, Campus Samambaia, \\ CEP 74001-970, Goiânia, GO, Brazil \\ 'Instituto de Química, Universidade Federal de Goiás - UFG, Campus Samambaia, CEP 74001-970, Goiânia, GO, Brazil \\ *e-mail: profacristiene@gmail.com
}

Received: July 13, 2016 - Accepted: November 8, 2016 - Distributed: May 31, 2018

\begin{abstract}
Salacia crassifolia (Mart. Ex. Schult.) G. Don. is a bush which belongs to Celastraceae family and occurs specially in Brazilian Cerrado. Its leaves, stem, seeds and fruits are popularly used for several medicinal purposes, such as antitumoral, antirheumatic, anti-inflammatory and antimicrobial. In this study, the mutagenic and antimutagenic activities of $S$. crassifolia stem bark fractions (hexane, ethyl acetate and hydroalcoholic) were evaluated by the Ames mutagenicity assay in Salmonella typhimurium TA98 and TA100 strains. By the obtained results, all S. crassifolia fractions did not significantly increase the number of prototrophic revertants for histidine (His ${ }^{+}$) in both S. typhimurium strains tested $(\mathrm{p}>0.05)$, suggesting absence of mutagenicity. Regarding antimutagenicity, the fractions ethyl acetate and hydroalcoholic significantly decreased the number of $\mathrm{His}^{+}$revertants colonies induced by positive control for strain TA98 ( $<$ 0.05), demonstrating protection against mutagenicity induced by 4-nitroquinolile1-oxide, whereas the hexane fraction did not show antimutagenic effect in this strain. In the TA100 strain, all fractions of S. crassifolia protected DNA against the harmful action of sodium azide, and the hexane fraction exhibited the greatest protection in this work. Thus, it's possible conclude that the fractions of S. crassifolia tested in this study could be used in chemoprevention.
\end{abstract}

Keywords: Salacia crassifolia, stem bark fractions, ames test, absence of mutagenicity, antimutagenicity.

\section{Mutagenicitade e antimutagenicidade de Salacia crassifolia (mart. Ex. Schult.) G. Don. avaliadas pelo teste de Ames}

\begin{abstract}
Resumo
Salacia crassifolia (Mart. Ex. Schult.) G. Don. é uma árvore que pertence à família Celastraceae e ocorre especialmente no Cerrado Brasileiro. Suas folhas, caule, sementes e frutos são popularmente utilizados para vários fins medicinais, tais como antitumoral, antirreumático, anti-inflamatório e antimicrobiano. Neste estudo, nós avaliamos as atividades mutagênica e antimutagênica de frações da casca do caule de S. crassifolia (hexânica, acetato de etila e hidroalcoólica) pelo ensaio de mutagenicidade de Ames em Salmonella typhimurium, cepas TA98 e TA100. Pelos resultados obtidos todas as frações de $S$. crassifolia não aumentaram significativamente o número de revertentes prototróficas para histidina $\left(\mathrm{His}^{+}\right)$em ambas as cepas de S. typhimurium testadas ( $\mathrm{p}>0.05$ ), sugerindo ausência de mutagenicidade. Em relação à antimutagenicidade, as frações acetate de etila e hidroalcoólica reduziram significativamente o número de colônias revertentes $\mathrm{His}^{+}$induzidas pelo controle positive para a cepa TA98 $(\mathrm{p}<0.05)$, demonstrando sua ação protetora contra a mutagenicidade induzida por 4-nitroquinolile1-oxide, enquanto a fração hexânica não demonstrou efeito antimutagênico nesta cepa. Na cepa TA100, todas as frações de $S$. crassifolia protegeram o DNA contra a ação lesiva de azida sódica, e a fração hexânica exibiu a maior proteção desse trabalho. Assim, concluímos que as frações de $S$. crassifolia testadas neste estudo poderiam ser utilizadas em quimioprevenção.
\end{abstract}

Palavras-chave: Salacia crassifólia, frações da casca do caule, teste de ames, ausência de mutagenicidade, antimutagenicidade.

\section{Introduction}

The use of plants for the treatment, cure and prevention of diseases is one of the forms of medical practice almost as old as the human species (Halberstein, 2005). Currently, the use of plant products for medicinal purposes still is quite

common throughout the planet. Furthermore, several drugs of great importance in clinical practice were obtained from plants widely used as medicinal by population, such as the morphine isolated from the opium poppy 
(Papaver somniferum) (Weid et al., 2004), and the vinblastine antitumor alkaloids and vincristine extracted of the plant Vinca rosea Linn (Brandão et al., 2010).

According Barreiro and Bolzani (2009), it is much more likely to find biological activity in plants guided by folk medicine than in randomly oriented plants. About $75 \%$ of the pure natural compounds found in pharmaceutical industry were isolated following recommendations of folk medicine (Newman and Cragg, 2007). However, many plants used with therapeutic purpose can also present risks to human health, since they can exhibit cytotoxic (Lima et al., 2013), genotoxic (Melo-Reis et al., 2011), and mutagenic activities (Ferreira et al., 2009).

Among the plants most used in Brazil for therapeutic purposes, whose pharmacological and phytochemical properties still have not been fully clarified is the species Salacia crassifolia (Mart. Ex. Schult.) G. Don. Commonly known as "bacupari-do-cerrado", "saputá" and "seputá", this plant is a bush which belongs to Celastraceae family and occurs specially in Brazilian Cerrado (Lombardi and Temponi, 2000). In traditional medicine, the infusion prepared with the leaves, stems or seeds of this plant is administrated orally to treat headaches, kidney disease, gastric ulcer, malaria and chronic cough. Moreover, the stem bark powder of bacupari is applied in the skin to treat pediculosis and skin cancer (Cavéchia and Proença, 2007; Oliveira et al., 2012).

There are few studies with $S$. crassifolia. Lima et al. (1972) and Theodoro (2009) showed that the bark extracts from the roots and stem of this plant present, respectively, potent antibacterial and antifungal activities. Other study conducted by Oliveira et al. (2012) revealed that two $S$. crassifolia stem bark fractions (hexane and ethyl acetate) exhibited significant cytotoxicity in vitro to MDA -MB-435 (melanoma), HCT-8 (human-colon), and SF-295 (CNS) using the MTT colorimetric method. Recently, using the micronucleus test in mice, our research team demonstrated absence of genotoxic activity for three S. crassifolia stem bark fractions (hexane, ethyl acetate and hydroalcoholic), which also showed antigenotoxic effect. In the same study, only one fraction presented cytotoxic activity (hexane), and the others presented anticytotoxic activity (Carneiro et al., 2013). However, more studies with $S$. crassifolia must be performed to evidence its effectiveness and the possible risks associated to its intake.

The Ames mutagenicity assay is part of the genotoxicity tests battery recommended by international regulatory agencies for product safety assessments (Pfuhler et al., 2007). This test uses different strains of Salmonella typhimurium to measure two classes of gene mutations, namely base pair substitution and small frameshifts (Mortelmans and Zeiger, 2000). Moreover, the Ames test is used to detect antimutagenic compounds. Therefore, the goal of this study was to evaluate the mutagenic effect of S. crassifolia stem bark fractions (hexane, ethyl acetate, and hydroalcoholic) by Ames mutagenicity test in Salmonella typhimurium strains TA98 and TA100. Considering the promising chemopreventive and antitumoral capacities of S. crassifolia, the protective effects against DNA damage induced by 4-nitroquinoline-1-oxide and sodium azide were also evaluated by Ames test.

\section{Material and Methods}

\subsection{Plant material}

In Anápolis, GO, Brazil, samples of $S$. crassifolia stem bark were collected $\left(16^{\circ} 12^{\prime} 49^{\prime \prime} \mathrm{S}, 48^{\circ} 57^{\prime} 57^{\prime \prime} \mathrm{W}\right)$ and identified by Dr. Mirley Luciene dos Santos. A voucher specimen (no. 5910) was deposited in the Central Herbarium of the Universidade Estadual de Goiás, in Anápolis. The hexane (HE), ethyl acetate (EA), and hydroalcoholic (HA) stem bark fractions of $S$. crassifolia were obtained in the Chemistry Institute at Universidade Estadual de Goiás, in Anápolis, GO, Brazil (Oliveira et al., 2012), and kindly provided by Dr. Caridad Noda Pérez.

\subsection{Chemical agents}

4-nitroquinoline-1-oxide (4NQO) and sodium azide were purchased from Sigma Chemical Co. (St. Louis, USA). $0.6 \%(\mathrm{w} / \mathrm{v}) \mathrm{NaCl}, 0.5 \mathrm{mM}$ histidine/biotin solution, nutrient broth, glucose minimal (GM) agar plates containing Vogel-Bonner (VB salts) medium E (50X) (magnesium sulfate, citric acid monohydrate, potassium phosphate dibasic anhydrous and sodium ammonium phosphate) and glucose solution $(10 \% \mathrm{v} / \mathrm{v})$, top agar supplemented with histidine/biotin $(0.5 \mathrm{mM})$, and enriched GM agar plates with biotin solution $(0.01 \%, \mathrm{w} / \mathrm{v})$ and histidine solution $(0.5 \%, \mathrm{w} / \mathrm{v})$, used for bacterial growth preparation, were purchased from Vetec Química Fina Ltda (Duque de Caxias, Brazil).

\subsection{Strains}

The Salmonella typhimurium auxotroph mutant strains TA98 (hisD3052-DuvrB rfa pKM101) and TA100 (hisG4-DuvrB rfa pKM101) were generously donated by Dr. Bruce N. Ames (University of California, Berkeley, CA, USA). The genetic backgrounds of these strains were confirmed as described by Maron and Ames (1983).

Before starting the experiments, this study was submitted and approved by the Research Ethics Committee of the Federal University of Goiás (CoEP-UFG, n 225/11).

\subsection{Experimental procedure}

The Ames mutagenicity assays in S. typhimurium strains were carried according to Maron and Ames (1983). In the mutagenic evaluation of $S$. crassifolia, $0.1 \mathrm{~mL}$ of bacterial suspension $\left(1-2 \times 10^{9}\right.$ cells $\left./ \mathrm{mL}\right)$ of each tester strain (TA98 and TA100) were incubated with $0.5,1.0,1.5$ and $2.0 \mathrm{mg} /$ plate of HE, EA and HA at $37^{\circ} \mathrm{C}$ for 25 minutes. These same doses of $S$. crassifolia were co-treated with the respective positive controls for each tester strain in the antimutagenic evaluation. A $2.0 \mathrm{~mL}$ aliquot of top agar were added to test tubes and poured into Petri dishes containing minimal agar medium. Each assay was performed three times in triplicate and included the positive control groups $(0.5 \mu \mathrm{g}$ of 4NQO for TA98 and $1.5 \mu \mathrm{g}$ of sodium azide for TA100), negative control group (sterile distilled water) and the solvent control group (DMSO). After incubation at $37{ }^{\circ} \mathrm{C}$ for 48 hours, the prototrophic revertants colonies for histidine $\left(\mathrm{His}^{+}\right)$were counted. 


\subsection{Statistical analysis}

The softwares Excel and Sigma Stat 3.5 were used in all analyses. All the results were tabulated and the experimental values were expressed as mean \pm standard deviation (SD). The data obtained from the experiments of mutagenicity were evaluated by ANOVA and Tukey's test for difference of means. The magnitude of the mutagenicity induction was measured by the mutagenic index (MI), calculated as the ratio between the number of colonies in the test group and the number of colonies in the solvent control group. A positive result for mutagenicity is considered when $\mathrm{MI}$ in treatment group is equal or twice higher than the negative control group (Maron and Ames, 1983).

To analyze the antimutagenicity, the obtained results were evaluated by ANOVA and compared to the respective positive controls. The $\mathrm{p}$ value $<0.05$ was considered significant, and the inhibition percentage of mutagenicity
(IP) induced by each mutagen (positive controls) was calculated using the Formula 1 (Sghaier et al., 2011):

$$
I P(\%)=[1-(T / M)] \times 100 \%
$$

Where $\mathrm{T}$ is the number of revertant colonies per test plate (positive control + test substance), and $\mathrm{M}$ is the number of revertant colonies per plate in the positive control.

\section{Results and Discussion}

The results of HE, EA, and HA mutagenicity and antimutagenicity are shown in Tables 1, 2 and 3, respectively. The data obtained for the positive, negative and solvent control groups indicated that the strains and controls were in agreement with the guidance established both by Maron and Ames (1983) and Mortelmans and Zeiger (2000).

Table 1. Means and standard deviation (SD) of histidine revertant colonies (obtained from three independent experiments carried out in triplicate), mutagenic index (MI), and inhibition percentage of mutagenicity (IP) for two strains of Salmonella typhimurium, TA98 and TA100, after treatment with diferent doses of the hexane fraction (HE) of Salacia crassifolia stem bark.

\begin{tabular}{|c|c|c|c|c|c|c|c|c|}
\hline \multirow{3}{*}{ Treatment } & \multicolumn{4}{|c|}{ Mutagenicity } & \multicolumn{4}{|c|}{ Antimutagenicity } \\
\hline & \multicolumn{2}{|l|}{ TA98 } & \multicolumn{2}{|l|}{ TA100 } & \multicolumn{2}{|l|}{ TA98 } & \multicolumn{2}{|c|}{ TA100 } \\
\hline & Means \pm SD & MI & Means \pm SD & MI & Means \pm SD & IP (\%) & Means \pm SD & IP (\%) \\
\hline Negative control $^{1}$ & $40 \pm 5^{\mathrm{A}}$ & 1.05 & $128 \pm 14^{\mathrm{A}}$ & 1.07 & $54 \pm 9^{\mathrm{D}}$ & - & $131 \pm 13^{\mathrm{D}}$ & - \\
\hline Solvent control ${ }^{2}$ & $38 \pm 2^{\mathrm{A}}$ & 1.0 & $119 \pm 10^{\mathrm{A}}$ & 1.0 & $57 \pm 17^{\mathrm{D}}$ & - & $115 \pm 16^{\mathrm{D}}$ & - \\
\hline Positive control ${ }^{3}$ & $457 \pm 36^{\mathrm{B}}$ & 12.03 & $1,383 \pm 182^{\mathrm{B}}$ & 11.62 & $564 \pm 32^{C}$ & - & $1,845 \pm 73^{\mathrm{C}}$ & - \\
\hline HE $0.5 \mathrm{mg} / \mathrm{plate}$ & $32 \pm 1^{\mathrm{A}}$ & 0.84 & $115 \pm 20^{\mathrm{A}}$ & 0.96 & $525 \pm 80^{C}$ & 6.92 & $1,364 \pm 93^{\mathrm{D}}$ & 26.08 \\
\hline HE $1.0 \mathrm{mg} / \mathrm{plate}$ & $37 \pm 13^{\mathrm{A}}$ & 0.97 & $115 \pm 18^{\mathrm{A}}$ & 0.96 & $515 \pm 35^{\mathrm{C}}$ & 8.69 & $1,394 \pm 118^{\mathrm{D}}$ & 24.45 \\
\hline HE $1.5 \mathrm{mg} / \mathrm{plate}$ & $33 \pm 8^{\mathrm{A}}$ & 0.87 & $116 \pm 10^{\mathrm{A}}$ & 0.97 & $516 \pm 52^{\mathrm{C}}$ & 8.52 & $1,097 \pm 146^{\mathrm{D}}$ & 40.55 \\
\hline HE $2.0 \mathrm{mg} / \mathrm{plate}$ & $41 \pm 10^{\mathrm{A}}$ & 1.08 & $122 \pm 11^{\mathrm{A}}$ & 1.02 & $502 \pm 63^{C}$ & 11.00 & $918 \pm 61^{\mathrm{D}}$ & 50.25 \\
\hline
\end{tabular}

${ }^{1}$ Distilled water. ${ }^{2}$ DMSO. ${ }^{3} 0.5 \mu \mathrm{g} /$ plate of 4 -NQO for TA98 and $1.5 \mu \mathrm{g} /$ plate of sodium azide for TA 100 . Mutagenicity:

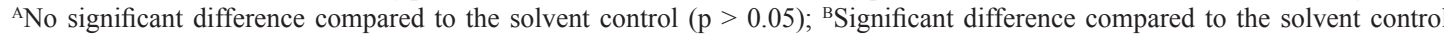
$(\mathrm{p}<0.05)$. Antimutagenicity: ${ }^{\mathrm{C}}$ No significant difference compared to the positive control $(\mathrm{p}>0.05) ;{ }^{\mathrm{D}}$ Significant difference compared to the positive control $(\mathrm{p}<0.05)$.

Table 2. Means and standard deviation (SD) of histidine revertant colonies (obtained from three independent experiments carried out in triplicate), mutagenic index (MI), and inhibition percentage of mutagenicity (IP) for two strains of Salmonella typhimurium, TA98 and TA100, after treatment with diferent doses of the ethyl acetate fraction (EA) of Salacia crassifolia stem bark.

\begin{tabular}{|c|c|c|c|c|c|c|c|c|}
\hline \multirow{3}{*}{ Treatment } & \multicolumn{4}{|c|}{ Mutagenicity } & \multicolumn{4}{|c|}{ Antimutagenicity } \\
\hline & \multicolumn{2}{|l|}{ TA98 } & \multicolumn{2}{|l|}{ TA100 } & \multicolumn{2}{|c|}{ TA98 } & \multicolumn{2}{|c|}{ TA100 } \\
\hline & Means \pm SD & MI & Means \pm SD & MI & Means \pm SD & IP (\%) & Means \pm SD & IP (\%) \\
\hline Negative control $^{1}$ & $38 \pm 9^{\mathrm{A}}$ & 1.22 & $132 \pm 17^{\mathrm{A}}$ & 0.95 & $40 \pm 10^{\mathrm{D}}$ & - & $120 \pm 12^{\mathrm{D}}$ & - \\
\hline Solvent control $^{2}$ & $31 \pm 5^{\mathrm{A}}$ & 1.0 & $139 \pm 20^{\mathrm{A}}$ & 1.0 & $31 \pm 13^{\mathrm{D}}$ & - & $123 \pm 36^{\mathrm{D}}$ & - \\
\hline Positive control $^{3}$ & $481 \pm 75^{\mathrm{B}}$ & 15.51 & $2,633 \pm 366^{\mathrm{B}}$ & 18.94 & $546 \pm 70^{\mathrm{C}}$ & - & $1,750 \pm 276^{\mathrm{C}}$ & - \\
\hline EA $0.5 \mathrm{mg} / \mathrm{plate}$ & $34 \pm 10^{\mathrm{A}}$ & 1.09 & $128 \pm 20^{\mathrm{A}}$ & 0.92 & $463 \pm 78^{C}$ & 15.21 & $1,253 \pm 210^{\mathrm{D}}$ & 28.4 \\
\hline EA $1.0 \mathrm{mg} / \mathrm{plate}$ & $38 \pm 7^{\mathrm{A}}$ & 1.22 & $126 \pm 21^{\mathrm{A}}$ & 0.90 & $425 \pm 102^{\mathrm{D}}$ & 22.17 & $1,111 \pm 130^{\mathrm{D}}$ & 36.52 \\
\hline EA $1.5 \mathrm{mg} / \mathrm{plate}$ & $37 \pm 5^{\mathrm{A}}$ & 1.19 & $126 \pm 15^{\mathrm{A}}$ & 0.90 & $374 \pm 91^{\mathrm{D}}$ & 31.51 & $1,066 \pm 175^{\mathrm{D}}$ & 39.09 \\
\hline EA $2.0 \mathrm{mg} / \mathrm{plate}$ & $39 \pm 7^{\mathrm{A}}$ & 1.26 & $125 \pm 11^{\mathrm{A}}$ & 0.89 & $341 \pm 80^{\mathrm{D}}$ & 37.55 & $890 \pm 78^{D}$ & 49.15 \\
\hline
\end{tabular}

${ }^{1}$ Distilled water. ${ }^{2}$ DMSO. ${ }^{3} 0.5 \mu \mathrm{g} /$ plate of 4 -NQO for TA98 and $1.5 \mu \mathrm{g} /$ plate of sodium azide for TA 100 . Mutagenicity: ${ }^{A}$ No significant difference compared to the solvent control $(\mathrm{p}>0.05)$; ${ }^{B}$ Significant difference compared to the solvent control $(\mathrm{p}<0.05)$. Antimutagenicity: ${ }^{\mathrm{C}}$ No significant difference compared to the positive control $(\mathrm{p}>0.05)$; ${ }^{\mathrm{D}}$ Significant difference compared to the positive control $(\mathrm{p}<0.05)$. 
Table 3. Means and standard deviation (SD) of histidine revertant colonies (obtained from three independent experiments carried out in triplicate), mutagenic index (MI), and inhibition percentage of mutagenicity (IP) for two strains of Salmonella typhimurium, TA98 and TA100, after treatment with diferent doses of the hydroalcoholic fraction (HA) of Salacia crassifolia stem bark.

\begin{tabular}{|c|c|c|c|c|c|c|c|c|}
\hline \multirow{3}{*}{ Treatment } & \multicolumn{4}{|c|}{ Mutagenicity } & \multicolumn{4}{|c|}{ Antimutagenicity } \\
\hline & \multicolumn{2}{|l|}{ TA98 } & \multicolumn{2}{|l|}{ TA100 } & \multicolumn{2}{|c|}{ TA98 } & \multicolumn{2}{|c|}{ TA100 } \\
\hline & Means \pm SD & MI & Means \pm SD & MI & Means \pm SD & IP (\%) & $\overline{\text { Means } \pm \text { SD }}$ & IP (\%) \\
\hline Negative control $^{1}$ & $41 \pm 4^{\mathrm{A}}$ & 1.1 & $118 \pm 10^{\mathrm{A}}$ & 1.08 & $42 \pm 8^{\mathrm{D}}$ & - & $149 \pm 20^{\mathrm{D}}$ & - \\
\hline Solvent control $^{2}$ & $37 \pm 6^{\mathrm{A}}$ & 1.0 & $109 \pm 9^{\mathrm{A}}$ & 1.0 & $44 \pm 6^{\mathrm{D}}$ & - & $127 \pm 13^{\mathrm{D}}$ & - \\
\hline Positive control ${ }^{3}$ & $367 \pm 28^{\mathrm{B}}$ & 9.91 & $1,831 \pm 226^{\mathrm{B}}$ & 16.79 & $395 \pm 64^{\mathrm{C}}$ & - & $1,950 \pm 106^{\mathrm{C}}$ & - \\
\hline HA $0.5 \mathrm{mg} / \mathrm{plate}$ & $39 \pm 8^{\mathrm{A}}$ & 1.05 & $128 \pm 23^{\mathrm{A}}$ & 1.17 & $269 \pm 66^{\mathrm{C}}$ & 31.90 & $1,514 \pm 113^{\mathrm{D}}$ & 22.36 \\
\hline HA $1.0 \mathrm{mg} / \mathrm{plate}$ & $38 \pm 7^{\mathrm{A}}$ & 1.02 & $145 \pm 24^{\mathrm{A}}$ & 1.33 & $234 \pm 61^{\mathrm{D}}$ & 40.76 & $1,485 \pm 74^{\mathrm{D}}$ & 23.85 \\
\hline HA $1.5 \mathrm{mg} /$ plate & $35 \pm 5^{\mathrm{A}}$ & 0.94 & $116 \pm 18^{\mathrm{A}}$ & 1.06 & $245 \pm 30^{\mathrm{D}}$ & 37.98 & $1,292 \pm 58^{\mathrm{D}}$ & 33.75 \\
\hline HA $2.0 \mathrm{mg} / \mathrm{plate}$ & $35 \pm 9^{\mathrm{A}}$ & 0.94 & $119 \pm 11^{\mathrm{A}}$ & 1.09 & $244 \pm 55^{\mathrm{D}}$ & 38.23 & $1,337 \pm 38^{\mathrm{D}}$ & 31.44 \\
\hline
\end{tabular}

${ }^{1}$ Distilled water. ${ }^{2}$ DMSO. ${ }^{3} 0.5 \mu \mathrm{g} /$ plate of 4 -NQO for TA98 and $1.5 \mu \mathrm{g} / \mathrm{plate}$ of sodium azide for TA 100 . Mutagenicity: ${ }^{\mathrm{A}}$ No significant difference compared to the solvent control $(\mathrm{p}>0.05)$; ${ }^{\mathrm{B}}$ Significant difference compared to the solvent control $(\mathrm{p}<0.05)$. Antimutagenicity: ${ }^{\mathrm{C}}$ No significant difference compared to the positive control $(\mathrm{p}>0.05)$; ${ }^{\mathrm{D}}$ Significant difference compared to the positive control $(\mathrm{p}<0.05)$.

In the Salacia crassifolia mutagenic activity evaluation (Tables 1, 2 and 3), the results obtained showed that all doses $(0.5,1.0,1.5$ and $2.0 \mathrm{mg} /$ plate $)$ of the fractions tested (HE, EA, and HA), were not mutagenic for the TA98 and TA100 strains, since there was no significant difference between the number of $\mathrm{His}^{+}$revertants of the treated groups and the solvent control group $(\mathrm{p}>0.05)$. Furthermore, none of the tested strains reached $\mathrm{MI} \geq 2$ or dose-response effect with the HE, EA, and HA treatments. Thus, by obtained results, Salacia crassifolia did not induce base-pair or frameshift mutations, suggesting that DNA does not seem to be a relevant target for this medicinal plant.

Likewise, by Ames mutagenicity assay, other species of the Celastraceae family presented similar results to those observed in this study. The root extract of $S$. oblonga did not present mutagenicity using the strains of S. typhimurium TA98, TA100, TA1535 and TA1537, and the dichloromethane and methanol extracts of Pleurostylia capensis not showed any mutagenic effect in strains TA98, TA97a, TA100 and TA102 (Flammang et al., 2006; Verschaeve and Van Staden, 2008).

Like the Ames mutagenicity test, the micronucleus test in bone marrow of rodents in vivo is widely used for detection of genotoxic and also antigenotoxic agents (Von Ledebur and Schmid, 1973). Recently, using the micronucleus test in mice bone marrow, our research team revealed that the three fractions of $S$. crassifolia studied in the present work (HE, EA and HA), did not cause significant increase in the frequency of micronucleated polychromatic erythrocytes compared to the solvent control group (Carneiro et al., 2013). Flammang et al. (2006) and Ribeiro et al. (2009) also did not found any statistically significant induction in micronucleated polychromatic erythrocytes of mice bone marrow treated with root extract of S. oblong $a$ and bark extract of Austroplenckia populnea (Reiss) Lundell (Celastraceae), respectively. In culture of peripheral blood lymphocytes from rat, any induction of chromosomal aberrations was not found after 90 consecutive days of treatment with root extract of $S$. oblonga (Flammang et al., 2007). The use of in vitro Ames mutagenicity test in combination with mice genotoxicity assays, has been recommended in several international guidelines to test the genotoxic/antigenotoxic activity of many types of substances (Pfuhler et al., 2007).

The carcinogenic agents 4-NQO and sodium azide were employed in the present study to evaluate the antimutagenic effect of $S$. crassifolia. 4-NQO induces potent intracellular oxidative stress, generating reactive oxygen species (ROS) such as superoxide radical and hydrogen peroxide. In addition, 4-NQO metabolic products can bind to DNA, mainly in guanine residues, causing mutations (Kanojia and Vaidya, 2006). Sodium azide induces the generation of ROS when associated with the activity of caspases during the apoptotic process (Zhang et al., 2011) and causes point mutations in DNA (base pairs transition and/or transversion) (Al-Qurainy and Khan, 2009).

In the antimutagenic evaluation of $S$. crassifolia (Tables 1, 2 and 3), our results indicated that almost all doses $(1.0,1.5$ and $2.0 \mathrm{mg} /$ plaque $)$ of the fractions ethyl acetate and hydroalcoholic were able to significantly inhibit the mutagenicity induced for 4NQO in strain TA98 $(p<0.05)$, while the hexane fraction did not exhibit any antimutagenic effect in this strain $(\mathrm{p}>0.05)$. Regarding the antimutagenicity of $S$. crassifolia in strain TA 100 , our results showed that all doses $(0.5,1.0,1.5$ and $2.0 \mathrm{mg} /$ plaque $)$ from the three fractions studied were able to significantly inhibit the mutagenicity induced by sodium azide $(\mathrm{p}<0.05)$, with the greatest inhibition percentage occurring for $\mathrm{HE}$ at dose $2.0 \mathrm{mg} /$ plate $(50.25 \%)$.

This difference observed in the response of the modulating action of $\mathrm{HE}$ can be attributed to different compounds present in this fraction. Possibly the HE, which has more non-polar chemical properties compared to the hydroalcoholic and ethyl acetate fractions, has less compounds capable to modulate the harmful actions of 
4-NQO in strain TA98. On the other hand, the greatest antimutagenic effect found in the present study was observed in HE. This fact was not unexpected, because in previous studies using the same fractions of $S$. crassifolia, the cytotoxic, antitumor and antigenotoxic activities of this plant were more pronounced in treatments with $\mathrm{HE}$ (Oliveira et al., 2012; Carneiro et al., 2013).

Recent epidemiological studies have shown that an increased consumption of fruits, vegetables and its secondary metabolites rich in polyphenolic antioxidants could reduce the risk of coronary heart disease and cancer (Hertog et al., 1993; Watzl, 2005). Species from the genus Salacia are rich in phenolic compounds such as quinonemethide triterpenes and flavonoids, which exhibit potent antioxidant activity, mainly due to their redox properties, absorption or free radicals scavenging that can attack biomolecules such as DNA (Tanabe et al., 2008; Vellosa et al., 2009). Also, in the species $S$. crassifolia, several phenolic compounds can be found (Lima et al., 1969; Rodrigues et al., 2015), however, further studies evaluating the antioxidant and antigenotoxic activities of these isolated compounds are needed.

In conclusion, all the $S$. crassifolia fractions evaluated did not exhibit mutagenic effect in bacteria. The fractions EA and HA demonstrated strong protective effect against the mutagenic actions of 4-NQO and sodium azide, while the hexane fraction showed protective effect only against the mutagenicity induced by sodium azide. Additionally, the hexane fraction exhibited the greatest antimutagenic effect observed in the present study, suggesting the presence of distinct compounds in each fraction. Therefore, S. crassifolia seems to be a rich source to the development of novel chemopreventive agents, however, more researches are necessary to isolate their active constituents and to clarify their mechanisms of action.

\section{Acknowledgements}

We thank our sponsors Coordenação de Aperfeiçoamento de Pessoal de Nível Superior (CAPES) and Universidade Federal de Goiás (UFG).

\section{References}

AL-QURAINY, F. and KHAN, S., 2009. Mutagenic effects of sodium azide and its application in crop improvement. World Applied Sciences Journal, vol. 6, pp. 1589-1601.

BARREIRO, E.J. and BOLZANI, V.S., 2009. Biodiversidade: fonte potencial para a descoberta de fármacos. Quimica Nova, vol. 32, no. 3, pp. 679-688. http://dx.doi.org/10.1590/S010040422009000300012.

BRANDÃO, H.N., DAVID, J.P., COUTO, R.D., NASCIMENTO, J.A.P. and DAVID, J.M., 2010. Chemistry and pharmacology of antineoplasic chemoterapeutical derivatives from plants. Quimica Nova, vol. 33, pp. 1359-1369.

CARNEIRO, C.C., SILVA, C.R., MENEZES, A.C., PÉREZ, C.N. and CHEN-CHEN, L., 2013. Assessment of genotoxic, cytotoxic, and protective effects of Salacia crassifolia (Mart. Ex. Schult.) G. Don stem bark fractions in mice. Genetics and Molecular
Research, vol. 12, no. 3, pp. 2167-2177. PMid:23884760. http:// dx.doi.org/10.4238/2013.July.3.1.

CAVÉCHIA, L.A. and PROENÇA, C.E.B., 2007. Resgate cultural de usos de plantas nativas do Cerrado pela população tradicional da região do atual Distrito Federal. Heringeriana, vol. 1, pp. 11-24.

FERREIRA, F.G., REGASINI, L.O., OLIVEIRA, A.M., CAMPOS, J.A.D.B., SILVA, D.H.S., CAVALHEIRO, A.J., SANTOS, R.A., BASSI, C.L., BOLZANI, V.S. and SOARES, C.P., 2009. Avaliação da mutagenicidade e antimutagenicidade de diferentes frações de Pterogyne nitens (Leguminosae), utilizando ensaio de micronúcleo em Tradescantia pallida. Revista Brasileira de Farmacognosia, vol. 19, no. 1a, pp. 61-67. http://dx.doi.org/10.1590/S0102$695 \times 2009000100014$.

FLAMMANG, A.M., EREXSON, G.L., MECCHI, M.S. and MURLI, H., 2006. Genotoxicity testing of a Salacia oblonga extract. Food and Chemical Toxicology, vol. 44, no. 11, pp. 18681874. PMid:16901601. http://dx.doi.org/10.1016/j.fct.2006.06.005.

FLAMMANG, A.M., EREXSON, G.L., MIRWALD, J.M. and HENWOOD, S.M., 2007. Toxicological and cytogenetic assessment of a Salacia oblonga extract in a rat subchronic study. Food and Chemical Toxicology, vol. 45, no. 10, pp. 1954-1962. PMid:17566623. http://dx.doi.org/10.1016/j.fct.2007.04.013.

HALBERSTEIN, R.A., 2005. Medicinal plants: historical and cross-cultural usage patterns. Annals of Epidemiology, vol. 15, no. 9, pp. 686-699. PMid:15921929. http://dx.doi.org/10.1016/j. annepidem.2005.02.004.

HERTOG, M.G.L., FESKENS, E.J.M., KROMHOUT, D., HERTOG, M.G.L., HOLLMAN, P.C.H., HERTOG, M.G.L. and KATAN, M.B., 1993. Dietary antioxidants flavonoids and the risk of coronary heart disease: the Zutphen elderly study. Lancet, vol. 342, no. 8878, pp. 1007-1011. PMid:8105262. http://dx.doi. org/10.1016/0140-6736(93)92876-U.

KANOJIA, D. and VAIDYA, M.M., 2006. 4-nitroquinoline-1-oxide induced experimental oral carcinogenesis. Oral Oncology, vol. 42, no. 7, pp. 655-667. PMid:16448841. http://dx.doi.org/10.1016/j. oraloncology.2005.10.013.

LIMA, D.C.S., SILVA, C.R., SAMPAIO, B.L., PAULA, J.R. and CHEN-CHEN, L., 2013. Antigenotoxic, and anticytotoxic activities of an ethanolic extract of Lafoensia pacari (Lythraceae) stem bark in bacteria and mice. Genetics and Molecular Research, vol. 12, no. 3, pp. 3887-3896. PMid:24085450. http://dx.doi. org/10.4238/2013.September.23.7.

LIMA, O.G., COELHO, J.S.B., MACIEL, G.M. and HERINGER, E.P., 1972. Substâncias antimicrobianas de plantas superiores: identificação de pristimerina como um componente ativo do "bacupari" do Araguaia, Salacia crassifolia (Mart.) G. Don. (Hippocrateaceae). Revista do Instituto de Antibióticos, vol. 12, pp. 19-24.

LIMA, O.G., D'ALBUQUERQUE, I.L., COELHO, J.S., MARTINS, D.G., LACERDA, A.L. and MACIEL, G.M., 1969. Antimicrobial substances from higher plants, XXX: antimicrobial and antineoplastic activity of pristimerin isolated from Prionostemma aspera, from the humid bushes of Pernambuco region. Revista do Instituto de Antibióticos, vol. 9, pp. 17.

LOMBARDI, J.A. and TEMPONI, L.G., 2000. Hipocrateaceae: flora dos estados de Goiás e Tocantins. 1st ed. Goiânia: Universidade Federal de Goiás. Coleção Rizzo.

MARON, D.M. and AMES, B.N., 1983. Revised methods for the Salmonella mutagenicity test. Mutation Research, vol. 113, no. 
3-4, pp. 173-215. PMid:6341825. http://dx.doi.org/10.1016/01651161(83)90010-9.

MELO-REIS, P.R., BEZERRA, L.S.A., VALE, M.A.A.B., CANHÊTE, R.F.R. and CHEN-CHEN, L., 2011. Assessment of the mutagenic and antimutagenic activity of Synadenium umbellatum Pax latex by micronucleus test in mice. Brazilian Journal of Biology $=$ Revista Brasileira de Biologia, vol. 71, no. 1, pp. 169-174. PMid:21437414. http://dx.doi.org/10.1590/ S1519-69842011000100024.

MORTELMANS, K. and ZEIGER, E., 2000. The Ames Salmonella/ microsome mutagenicity assay. Mutation Research, vol. 455, no. 1-2, pp. 29-60. PMid:11113466. http://dx.doi.org/10.1016/ S0027-5107(00)00064-6.

NEWMAN, D.J. and CRAGG, G.M., 2007. Natural products as sources of new drugs over the last 25 years. Journal of Natural Products, vol. 70, no. 3, pp. 461-477. PMid:17309302. http:// dx.doi.org/10.1021/np068054v.

OLIVEIRA, C.R., MENEZES, A.C.S., MORAES, M.O., VIEIRA, L.M., PEREIRA, A.G., LIMA, R.S. and SANTOS, M.L., 2012. Avaliação citotóxica em três linhagens de células tumorais das frações obtidas da casca do caule de Salacia crassifolia (Mart. Ex. Schult.) G. Dom. (Celastraceae). Revista Colombiana de Ciências Químico-Farmacêuticas, vol. 41, pp. 133-142.

PFUHLER, S., ALBERTINI, S., FAUTZ, R., HERBOLD, B., MADLE, S., UTESCH, D. and POTH, A., Gesellschaft fuer Umwelt-Mutationsforschung, 2007. Genetic toxicity assessment: employing the best science for human safety evaluation Part IV: Recommendation of a working group of the Gesellschaft fuer Umwelt-Mutationsforschung (GUM) for a simple and straightforward approach to genotoxicity testing. Toxicological Sciences, vol. 97, no. 2, pp. 237-240. PMid:17303579. http:// dx.doi.org/10.1093/toxsci/kfm019.

RIBEIRO, J.C., ANDRADE, S.F., BASTOS, J.K. and MAISTRO, E.L., 2009. Evaluation of the genotoxic potential of Austroplenckia populnea (Reiss) Lundell chloroform fraction from barkwood extract in rodent cells in vivo. Brazilian Journal of Biology = Revista Brasileira de Biologia, vol. 69, no. 4, pp. 1141-1147. PMid:19967186. http://dx.doi.org/10.1590/S151969842009000500019 .

RODRIGUES, V.G., DUARTE, L.P., SILVA, R.R., SILVA, G.D.F.A., MERCADANTE-SIMÕES, M.O.C., TAKAHASHIA, J.A., MATILDESA, B.L.G., FONSECA, T.H.S.D., GOMES, M.A.D. and VIEIRA-FILHO, S.A., 2015. Salacia crassifólia (Celastraceae): chemical constituents and antimicrobial activity. Quimica Nova, vol. 38, pp. 237-242.
SGHAIER, M.B., BHOURI, W., BOUHLEL, I., SKANDRANI, I., BOUBAKER, J., CHEKIR-GHEDIRA, L. and GHEDIRA, K., 2011. Inhibitory effect of Teucrium ramosissimum extracts on aflatoxin B1, benzo[a]pyrene, 4-nitro-o-phenylenediamine and sodium azide induced mutagenicity: correlation with antioxidant activity. South African Journal of Botany, vol. 77, no. 3, pp. 730740. http://dx.doi.org/10.1016/j.sajb.2011.03.014.

TANABE, G., SAKANO, M., MINEMATSU, T., MATUSDA, H., YOSHIKAWA, M. and MURAOKA, O., 2008. Synthesis and elucidation of absolute stereochemistry of salaprinol, another thiosugar sulfonium sulfate from the ayurvedic traditional medicine Salacia prinoides. Tetrahedron, vol. 64, no. 43, pp. 10080-10086. http://dx.doi.org/10.1016/j.tet.2008.08.010.

THEODORO, P.N.E.T., 2009. Atividade in vitro de plantas da medicina tradicional do Cerrado em dermatófitos e leveduras. Brasília: Faculdade de Ciências da Saúde da Universidade de Brasília. Dissertação de Mestrado em Ciências da Saúde.

VELLOSA, J.C.R., KHALIL, N.M., GUTIERRES, V.O., SANTOS, V.A.F.F.M., FURLAN, M., BRUNETTI, I.L. and OLIVEIRA, O.M.M.F., 2009. Salacia campestris root bark extract: peroxidase inhibition, antioxidant and antiradical profile. Brazilian Journal of Pharmaceutical Sciences, vol. 45, no. 1, pp. 99-107. http:// dx.doi.org/10.1590/S1984-82502009000100012.

VERSCHAEVE, L. and VAN STADEN, J., 2008. Mutagenic and antimutagenic properties of extracts from South African traditional medicinal plants. Journal of Ethnopharmacology, vol. 119, no. 3, pp. 575-587. PMid:18602977. http://dx.doi.org/10.1016/j. jep.2008.06.007.

VON LEDEBUR, M. and SCHMID, W., 1973. The micronucleus test: methodological aspects. Mutation Research, v. 19, pp. 109-117.

WATZL, B., 2005. Consumption of vegetables and fruits and risk of breast cancer. JAMA Network, vol. 293, no. 18, pp. 2209-2210. PMid:15886371

WEID, M., ZIEGLER, J. and KUTCHAN, T.M., 2004. The roles of latex and the vascular bundle in morphine biosynthesis in the opium poppy, Papaver somniferum. Proceedings of the National Academy of Sciences of the United States of America, vol. 101, no. 38, pp. 13957-13962. PMid:15353584. http://dx.doi.org/10.1073/ pnas.0405704101.

ZHANG, L., XIN-RUI, C., JUAN-JUAN, H.U., LAN, S. and GUAN-HUA, D., 2011. Neuroprotective effects of hyperoside on sodium azide-induced apoptosis in PC12 cells. Chinese Journal of Natural Medicine, vol. 9, pp. 450-455. 